\title{
CORPO, LINGUAGEM E REAL: O SOPRO DE EXU BARÁ E SEU LUGAR NA COMUNICAÇÃO
}

\author{
Florence Marie Dravet \\ Universidade Católica de Brasília \\ Brasília, DF, BR.
}

\section{Resumo}

O presente artigo busca ensaiar um pensamento-corpo que permita conceber a comunicação como um processo no qual corpo, linguagem e real estejam integrados e sejam elementos vivos, animados por um mesmo sopro que os atravessa. Para tanto, observamos a noção de Exu Bará para os nagôs afro-brasileiros tal como é vivida nos terreiros. Analisamos seus mitos e sua linguagem, suas formas de manifestação, seus gestos para apreender seu sentido semântico e sensorial. Adotamos uma metodologia poética na tentativa de alcançar um pensamento em movimento. E chegamos a uma representação geométrica para o corpo que qualificamos de artístico-filosófica e que figura o corpo como uma rosa no centro de um losango, um elemento vivo em plena interação dinâmica com o seu meio.

Palavras-chave: Comunicação; corpo; linguagem; Exu; sopro.

\section{BODY, LANGUAGE AND THE REAL: THE BREATH OF EXU BARÁ AND ITS PLACE IN COMMUNICATION}

\begin{abstract}
The present article seeks to essay a body-thought that allows perceiving communication as a process in which body, language and real are integrated, living elements, animated by the same breath that crosses them. To this end, we look at the notion of Exu Bará for Afro-Brazilian nagôs as experienced in its communities. We analyze its myths and its language, its forms of manifestation, his gestures, to seize its semantic and sensorial sense. We adopt a poetic methodology in an attempt to achieve a thought in motion. And we came to a geometric representation for the body, qualified as philosophical and artistic, that figures the body like a rose in the centre of a rhombus, a living element in broad dynamic interaction with its environment.
\end{abstract}

Keywords: Communication; body; language; Exu; breath.

Partimos aqui da necessidade de construir um pensamento que permita conceber a comunicação como um processo no qual corpo, linguagem e real estejam integrados e sejam elementos vivos, animados por um mesmo "sopro" (FÉDIDA, 1985) que os atravessa, ainda que na modalidade do invisível e - talvez - do incompreensível. Como linguagem, entendemos a infinitude das combinações possíveis entre palavras, imagens e imaginação, todas elas atravessadas pelo sopro que anima a fala e o gesto. Como noção experimental para esse pensamento, convocaremos Exu Bará1 e analisaremos seu papel na comunicação e na constituição de uma ontologia possível para os nagôs da África e do Brasil. Para tanto, será preciso pensar o incompreensível e recorrer, uma vez mais, à poética como única maneira de vincular na linguagem a "memória inconsciente", o "passado

\footnotetext{
* Florence Dravet é professora de Estética na Universidade Católica de Brasília. É doutora em Didactologia das Línguas e Culturas, com tese em Comunicação Intercultural, na Universidade de Paris III - Sorbonne-Nouvelle (2002). Fez pós-doutorado em Comunicação, pela Universidade de Brasília (2011). Atual coordenadora do Programa de Pós Graduação em Comunicação da Universidade Católica de Brasília. Estuda os fenômenos da sensibilidade, do imaginário, do feminino, do corpo e do poético, as tradições afrobrasileiras e a transculturalidade. Email: flormd@gmail.com
} 
anacrônico" e o "presente reminiscente" (FÉDIDA, p. $23,1985)$ a fim de melhor conceber esse "sopro", no limite do incompreensível.

Há muito o que explicar aqui. Começaremos por uma justificativa de nossas escolhas: por que recorrer, para entender o fenômeno apontado, à noção nagô de Exu Bará? No que a poética se apresenta como meio de aproximação do incompreensível e como pode constituir uma metodologia? De onde vem essa noção de sopro? E em que medida ela se aproxima de Exu Bará? Para responder a essa última pergunta, que constitui nossa problemática central, proporemos uma experimentação do método.

\section{De Kamper à África: trazendo as margens para o centro da discussão}

Recentemente, tivemos acesso à tradução de uma obra, ainda inédita no Brasil, do pensador alemão Dietmar Kamper (prelo). Trata-se de um texto escrito às vésperas de sua morte, no qual o pesquisador manifesta suas esperanças no humano e sua crítica radical à civilização ocidental. Nesse livro, Kamper busca um "pensamento-corpo" como resposta a uma "estética da ausência" em que a remoção do corpo é fato consumado da civilização. Nela, "somente o que tem uma imagem tem realidade (...) Tudo o mais, tudo o que for vivo vai para a margem e, em seguida, é excluído. Em relação a tal violência a única coisa que se pode reclamar para o corpo vivo é invisibilidade" (idem, p.71).

Pouco se lê Dietmar Kamper; no entanto, sua contribuição para o pensamento comunicacional nos parece salutar e necessária, como forma de renovação e arejamento. Decidimos trazer seu pensamento para a reflexão não apenas porque necessitamos ouvir melhor aqueles que permanecem às margens e propõem pensamentos radicais, mas também porque as ideias por ele propostas a respeito do lugar do corpo na comunicação, na sociedade ocidental e mediática, soam urgentes:

Hoje, o caminho é de volta e com passos para trás. Chegamos literalmente a 'nada', com letra minúscula, na nulodimensão do pensamento digital. E menos do que nada não existe. Até aqui foi um longo caminho. Precisamos percorrê-lo de volta: até o mundo do corpo, no qual possamos ser corpos de corpos. (Idem, p. 51)

Percebe-se, portanto, aqui, um clamor pela volta do corpo. Mas não o corpo pensado apenas como meio de expressão, objeto teatral ou sistema fisiológico. O corpo pensado de maneira integrada, como parte da comunicação em vários níveis: no nível transcendente e imanente, poderíamos dizer. O corpo poético, o corpo vivo, o corpo que rastreia e sente, o corpo atravessado, o corpo-médium, o corpo-circulação, fluxo, trânsito. Voltaremos a pensar esse corpo e retomaremos o "pensamento-corpo" de Dietmar Kamper mais a frente.

O que cabe agora explicar é por que recorremos ao pensamento africano e por que propomos estabelecer esse vínculo nocional entre o pensamento-corpo em Kamper e Exu Bará afrobrasileiro. Primeiro, é preciso falar do lugar ocupado pela antiguidade em qualquer reflexão sobre a linguagem, o pensamento e o corpo, pois o Homem da antiguidade é justamente aquele que inventou os gestos de que somos os atores contemporâneos; inventou os textos, as imagens e todas as formas de figuração da cultura que ora seguimos veiculando na arte, na literatura, no imaginário. Trata-se, já, aqui, da primeira abordagem ao sopro, esse golpe de ar que conduz, propaga, difunde todo gesto e, por consequência, todo desejo, de um lugar a outro e através dos tempos. Aquilo que Benjamin (1940/1987) chama de "sopro do ar no qual viviam os homens de ontem" e que cabe ao historiador "sentir", não só através do relato factual da história, mas também da memória sensorial; esta que a arte inscreveu nas pedras, nos túmulos, nas tragédias. Esta que não faz outra coisa senão figurar o mito.

Aqui, experimentaremos sentir o sopro do ar dos antigos não apenas através dos mitos gregos, mas também, e sobretudo, através dos mitos africanos. Este deslocamento nos é caro, porque falamos a partir do Brasil, e neste país, respiramos um ar impregnado por uma antiguidade plural: a nativa, a colonial e a africana trazida pelos exilados do continente negro que aqui foram instalados e trouxeram consigo sua própria antiguidade. Obviamente, o Brasil - ou talvez devamos dizer um Brasil letrado - respira um ar pleno de mitos gregos, trazidos pelos Europeus que aqui instauraram uma cul- 
tura que se pretendeu dominante, escrita e civilizada. Enquanto os Europeus trouxeram seus livros, seus textos de Lei, sua imprensa e seu sistema de transmissão de conhecimento baseado na escrita, os Africanos não carregaram nada consigo além de sua memória, sua oralidade e seus corpos. A memória africana foi, no Brasil, em tudo dependente do corpo e da sensorialidade. E é nisso que ela nos interessa particularmente.

Trata-se de uma antiguidade ancestral, que se manifesta pela narração do mito, cujo modo de transmissão se dá, propriamente, pelo sopro que atravessa os corpos, nos gestos e na fala. Os continuadores da tradição africana no Brasil cultuam essa antiguidade sob a categoria de ancestralidade, rendendo-lhe cultos que chegam a organizar parte da vida nos terreiros. Não entraremos na descrição desses cultos, por não constituírem nosso objeto aqui; porém, vale lembrar que quando a antiguidade se manifesta na memória sensorial e não está inscrita em pergaminhos e pedras, ela necessita estar viva no corpo das pessoas, no corpo mediador da memória sensorial. Daí esse corpo ganhar um lugar de honra, com títulos que lhe conferem sacralidade e se manifestam nos gestos, na constituição e na própria produção de sentidos. A força que anima o corpo sagrado de todo ser vivo é chamada, na tradição nagô, de Exu Bará. Veremos mais adiante os desdobramentos dessa noção e seu papel na comunicação, papel que qualificamos de ontológico, colocando desde já a comunicação como fundadora do ser e mediadora de sua existência no mundo. Sendo assim, vemos que temos algo a aprender sobre a comunicação, tanto através do pensamento-corpo e seu sopro, quanto através do sopro de Exu Bará.

\section{Pensar o incompreensível: a poética como método}

Como apreender esse sopro que atravessa e anima todas as coisas, que está no corpo, nas obras de arte, na fala, no gesto e em todas as coisas vivas? Didi-Huberman (2005), em um ensaio sobre a obra do filósofo e psicanalista Pierre Fédida, explica alguns posicionamentos metodológicos que qualifica de "poéticos", começando por tratar da "necessidade de pôr em movi- mento aquilo que nossos hábitos intelectuais querem insistentemente estancar" (FÉDIDA apud DIDI-HUBERMAN, 2005, p. 22). Mais que isso, a expressão de um pensamento em movimento não se contenta com a abstração que torna excessivamente mental a percepção da coisa a ser enunciada. É necessário que o pensamento em movimento se manifeste através de uma sensação, que possa ser percebida no corpo, que ganhe plasticidade, ritmo, respiração. As palavras e a fala nasceriam, portanto, de uma troca de ar entre o ambiente externo, pleno de vida, de sensações e informações, e o interior por sua vez também pleno de afetos, emoções e pensamentos. Assim, pode-se dizer que o pensamento em movimento capaz de apreender o sensível nasce de uma respiração à qual é preciso atentar, de uma troca de ar, da circulação desse ar atravessando e animando as coisas, o mundo, os corpos.

$\mathrm{O}$ ar, portanto, possibilita uma troca entre informações atmosféricas (do ambiente) e informações viscerais (da interioridade), pelo viés de algo móvel, fluido, dinâmico. A proposta metodológica poética - nisso que ela é uma poiesis, um fazer criativo - pressupõe recorrer ao veículo airoso da metáfora, esse fluxo que atravessa, essa imagem dinâmica que diz sem aprisionar, que desperta o sentir fazendo vivenciar o rastro da coisa evocada. Por isso, recorreremos ao mito e a suas vivências rituais. Tanto com a metáfora, como com a fala do corpo, "a potencialidade do sentido (semântico) é potência de sentidos (sensoriais)" (FÉDIDA apud DIDI-HUBERMAN, ibid. p. 44). O simbólico vira matéria, o significante torna-se sopro que conduz às reminiscências do passado anacrônico ancestral. É assim que a representação se vê pulverizada pela proximidade material da emanação e perde sua força enquanto representação de um objeto exterior. Já, a fala ou o gesto tornam-se evocação de uma sensação interior inefável, ganhando potência no mundo das representações. Talvez fosse nesse sentido que Benjamin falava da "aura" de uma obra de arte. Com a reprodução técnica, perde-se o sopro do gesto contido no ato de pintar. A representação do objeto se multiplica e circula, mas não seu sopro. Algo se perde: brilho, quentura, intensidade, vida, afeto, sopro?

O fato é que ao querermos apreender o sopro que anima a linguagem, estamos tocando no incompreen- 
sível. Naquilo que nenhuma semiologia conseguiu apreender, por mais que tenha pretendido extrair uma "Teoria geral do signo" ou mesmo uma "Semiótica das paixões". Marie-Thérèse Mathet, no prefácio de seu livro sobre o Incompreensível na literatura, no visual e no real, afirma: "A escritura é incompreensível naquilo que ela mesma não compreende do real"; então, "não há código nem deciframento possível" e é preciso aceitar que "o sujeito deixa de ser a instância soberana do conhecimento" e que "o texto torna-se sujeito" (2003, p. 9-15). Sendo assim, nossa metodologia aqui será poética, dando o papel de mediadora do pensamento à linguagem do mito, pondo o próprio gesto e sua plasticidade no primeiro plano da observação, aproximando-nos da ideia de um "pensamento-corpo". É por isso que a geometria será também um recurso de aproximação do incompreensível sopro que anima o corpo. Atentaremos para a fala, o gesto e a forma que as narrativas do mito assumem quando vivenciadas através de diversos ritos, ora cotidianos, ora literários ou, ainda, litúrgicos. Mas também atentaremos para a mesma perspectiva posta em negativo: o silêncio, as zonas de indefinição, de inexatidão, o incompreensível contido na relação entre corpo, real e linguagem e que também pertence ao sopro. Para entendermos o sopro, portanto, vamos a Exu Bará e a suas narrativas, apresentações rituais, suas falas e gestos. Vamos também ao sopro contido na sua fala, no seu girar, na sua gargalhada, no seu movimento incessante e, por fim, na potência de sua força de vontade, a um só tempo coletiva e individual.

\section{O sopro de Exu Bará: experimentação do método}

Procederemos aqui por aproximação de noções. Colocaremos lado a lado a figura de Exu Bará, já entendida e explicada por Santos e Santos (2014) como o "princípio de comunicação" (p.107), e a noção de comunicação como fundadora do ser e mediadora de sua existência no mundo, já desenvolvida e exposta por nós em trabalhos anteriores (CASTRO e DRAVET, 2014). Mostraremos as relações de Exu Bará com os princípios masculino e feminino da existência e com a transmissão de sentidos tanto femininos como masculinos. Veremos que a força de Exu Bará reside na fala, no riso e no movimento, três manifestações complementares do sopro. E que, como se vê em uma de suas representações - o caracol -, essa força é espiral, podendo ser centrífuga e centrípeta, portanto motora, transformadora, dinâmica, mas também criadora e destruidora a um só tempo.

\subsection{Exu Bará, um poeta no corpo}

$E x u$, ao nascer, já tem fome. Exige de sua mãe que lhe dê comida. Ele come assim todos os peixes, todos os preás, todos os pássaros e todos os animais da terra. Depois que termina de comer todos os seres vivos da terra, do mar e do ar, diz para sua mãe que terá de comê-la, porque ainda está com fome. E sua mãe, sempre solícita em dar alimento ao filho, lhe responde que coma. Exu devora então a própria mãe. Quando ele diz a seu pai que também terá de comê-lo porque ainda está com fome, o pai o persegue e com sua espada o divide em duzentos pedaços, espalhando-os sobre a terra. Mas, do último pedaço que restou, Exu ergue-se novamente, inteiro, e volta a correr; novamente o pai o persegue e o divide em duzentos pedaços e assim, nove vezes sucessivas, até que todos os recantos do mundo estejam povoados por pedaços de Exu, que se tornam novos Exus. Não sabendo mais o que fazer, seu pai vai procurar Orumilá (o detentor do oráculo de Ifá) e este lhe ensina que volte à terra, chame pelo filho dividido e lhe peça o que quiser. Exu, explica Orumilá, haverá de ser a força que realizará sobre a terra todas as necessidades de seu pai. E assim, quando o pai pede que lhe devolva sua mãe e os seres que comera, Exu obedece e vomita tudo: peixes, preás, pássaros, animais e a própria mãe. Assim fazendo, ele devolve a vida, mas também entrega aos seres seu próprio sopro. $\mathrm{E}$ os seres passam a ser animados com a força de Exu, uma força dinâmica e viva: o princípio animador da existência, oriundo da união das forças fecundas do ar (Oxalá, o pai) e geradoras da água (Oduduá, a mãe). Por isso, se diz que em tudo o que há de vivo, há Exu. E que cada ser vivo possui o seu Exu Bará, ou seja, a força de Exu individualizada no corpo.

É preciso entender que Exu é o primeiro ser criado. Ele é filho do pai e da mãe, dos princípios universais 
masculino e feminino. Mas esses princípios universais - o mar e o ar, Olodumare e Ododua, Oxalá e Iemanjá e assim por diante, de acordo com a concepção - já estão no mundo mesmo antes de haver o mundo. São, por isso mesmo, princípios. Já Exu, é filho. É o elemento gerado. O terceiro que possui em si os dois princípios universais do masculino e do feminino. Por isso ele é andrógino. Sobretudo, é aquele que faz o elo entre a vida divina e primordial do princípio e a vida dos seres que passaram a habitar o mundo. Nesse sentido, quando Exu come e vomita os seres, infunde neles a centelha divina de que ele é fruto, os anima com a força dinâmica dos princípios universais, a força divina primordial. Dito de outro modo, no "presente reminiscente" está o "passado anacrônico". Com isso, ele transita facilmente entre passado, presente e futuro; é a um só tempo ancião, adulto e criança. E mais, Exu é o canal, o transmissor, a mensagem, o código, o trânsito. É o fluxo da comunicação entre um e outro, o sopro da memória que reúne passado e presente, o sopro do ciclo da vida que reúne ancestralidade e descendência.

É interessante notar que o ato de comunicação no mito original não se dá quase em palavras, mas se dá sempre pela boca, pelo ato de comer e vomitar. Esse ato de voracidade de um recém-nascido e posterior devolução, sobretudo da mãe, necessita ser mais bem compreendido porque parece ser a chave de todo o sentido de Exu. Outro mito pode esclarecer esse papel de devorador-restituidor. Trata-se do mito de Oxetuá, um dos caminhos do oráculo de Ifá. Nesse mito, segundo Santos e Santos (2014), Oxetuá é o caminho através do qual Exu fala. É também um caminho nascido da energia feminina de Oxum e da energia masculina dos dezesseis Orixás fecundadores. Oxetuá nasce menino, conforme a vontade de sua mãe Oxum, e é o único caminho que consegue alcançar Olodumare - o grande Deus - para que as oferendas dos Orixás que povoam a terra possam ser entregues e aceitas pelo Deus criador, de maneira que este se lembre de cuidar da terra, enviando a chuva e restaurando a ordem sem a qual o mundo ficaria mergulhado num caos permanente. Oxetuá, o décimo sétimo caminho, e Exu, o dinamismo, se juntam para que as oferendas cheguem a seu destino. Ambos são, portanto, aqueles que garantem a circula- ção das informações que devem fluir entre o mundo dos vivos e o mundo divino. É por isso que qualquer oferenda só pode ser feita com a intermediação de $E x u$.

No ritual afro-brasileiro, em que todo e qualquer ato é feito com uma oferenda (a comida se oferta para fazer pedido, restaurar o equilíbrio, fazer um agradecimento, etc), sempre se faz primeiro uma oferenda a $E x u$, para então pedir-lhe que a leve às outras forças, assim como narrado no mito. Na linguagem ritualística, diz-se que "Exu come primeiro". Sendo assim, ele come primeiro para poder levar as mensagens a serem entregues aos outros Orixás. Se Exu não come, a oferenda não é entregue. Todos dependem dele, enquanto ser intermediário, devorador e restituidor de força.

Mas sua fala não é direta. Exu carrega a fala das forças do mundo. O ritual do padê (tal como descrito por Santos e Santos, mas também, tal como se vive em todos os terreiros nagôs do Brasil, com pequenas variações) encena a relação entre Exu e a ancestralidade masculina e feminina. Segundo Santos e Santos:

Exu como princípio da vida individual, que simboliza os procriados, promove as condições necessárias para que a existência individual aconteça e cumpra seu ciclo. Como princípio dinâmico, ele movimenta e controla a harmonia das relações do indivíduo, da comunidade e do sistema, permitindo, portanto, a união e o desenvolvimento equilibrado das partes. (p. 136)

Ele é o intermediário, mas também, e por isso mesmo, aquele de quem todos dependem. Esse poder de $E x u$, atuando numa relação direta entre forças divinas e forças viventes, imanentes, se torna ainda mais evidente quando se percebe que este não está apenas no nível transcendente dos deuses, mas existe dentro de cada corpo, de cada ser vivo. Porque no início, ao nascer, Exu devorou a tudo e todos e imprimiu neles sua força primordial e divina pelo ato da regurgitação, tornando-se, em cada ser, Exu Bará: o rei do corpo. Sendo assim, há algo de divino, de original em cada ser vivo, que se expressa pelo sopro que Exu infundiu ao nascer a todos os seres. Os seres vivos e Exu estão todos intrinsecamente ligados pela força do Bará, do corpo. 


\subsection{Exu Bará, um poeta na linguagem}

Além dessa relação com a comida, que passa pela boca, Exu é a voz, o mensageiro, aquele que avisa, alerta, prevê, aconselha. Diz-se que aquilo que Exu fala sempre deve ser seguido, pois que dele todos dependem para estar em harmonia com as forças do mundo. Todos os caminhos de Ifá falam através da boca de Exu. Um dos mitos conta que os quatrocentos deuses que habitavam o mundo deram um pedaço de sua boca a Exu para que este falasse por eles ao grande Olodumare.

Os búzios usados no jogo oracular afro-brasileiro são, aliás, muito semelhantes a dentes e, por vezes, considerados como bocas que falam. São dezesseis bocas-búzios (assim como são dezesseis dentes em cada maxilar), mas a décima sétima é Oxetuá, a fala de Exu à qual não se recorre, porque será certeira, intransigente, irremediável. Oxetuá, portanto, não fala diretamente, apenas é o possibilitador da fala dos dezesseis caminhos. Talvez seja ele a força que anima a própria boca. $\mathrm{O}$ sopro?

Provavelmente por isso, na ritualística, Exu aparece rindo, gargalhando, girando em movimentos espiralares e falando, trazendo recados, mensagens de outros Orixás. Toda a sua atividade - que é em si extremamente dinâmica e plural - passa pela boca: o giro redunda em gargalhada, em fala, em sopro. $\mathrm{O}$ esquema proposto por SANTOS e SANTOS (2014, p. 30) que reproduzimos aqui é bem esclarecedor a respeito dessa natureza dinâmica e autoexpansiva de Exu de configuração espiralar. Trata-se do Okotô, o caracol que, de uma perna só, rodopia por toda a terra e se expande ao infinito:

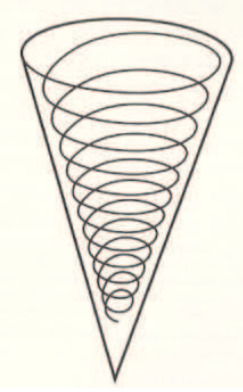

Caracol-pilão, símbolo de crescimento. Fonte: SANTOS e SANTOS, 2014, p. 30

Quando Exu cala, algo está para acontecer. Ele está armando, tramando. Ou seja, seu silêncio carrega em si toda a potencialidade de sua fala. Isso nos remete diretamente a uma altercação de Didi-Huberman sobre a linguagem (2005, p. 9): “Accentuer les mots pour faire danser les manques et leur donner puissance, consistance de milieu en mouvement. Accentuer les manques pour faire danser les mots et leur donner puissance, consistance de corps en mouvement".2 As palavras ganham corpo, os silêncios ganham potência enquanto meio, atmosfera. Assim como falamos acima que o sopro da fala é uma respiração que possibilita a troca entre o atmosférico exterior e o visceral interior, Exu também exerce com seu sopro vital esse papel de mediador entre o mundo exterior em toda sua extensão aberta - inclusive até a mais transcendente das concepções de abertura, a divindade - e o mundo interior em toda sua profundidade, individualizada no singular-universal de cada ser.

Enquanto ser andrógino, Exu nasceu menino mas comeu sua mãe, tornando-se então conhecedor dos mistérios da placenta e da cabaça-ventre. Com isso, ele é também um ser cuja linguagem é ao mesmo tempo masculina e feminina. Isso significa que ele fala em positivo e em negativo, na luz e nas trevas, na palavra e no silêncio. É, em si, uma metáfora do feminino e do masculino (o menino que ao nascer comeu todos os seres da terra inclusive sua mãe; o menino que se multiplica pela ação da espada de seu pai e se autoregenera) e sua linguagem é pura metáfora: é, a um só tempo, o signo semiótico e o fenômeno sensível, o sentido e o sentir. Sua fala é potencialidade do sentido semântico, mas também é potência de sentidos sensoriais, uma vez que Exu está fora e dentro do corpo. Segundo a terminologia nagô, Exu é Elegbara (a força do princípio universal dinâmico do mundo) e Bará (a força singular-universal que anima cada corpo). Ele fala com a voz e com o corpo ao mesmo tempo.

Por ser puro movimento, Exu dança. Não basta dizer que ele se expressa pelo corpo. É algo mais: sua força atravessa os corpos em todos os sentidos, movimentando-os. E os corpos falam a linguagem que Exu lhes infundiu com seu sopro. Tornam-se, então, não apenas meio de expressão, mas também receptáculo da fala do mundo. Com a concepção africana do corpo vivo animado por Exu Bará, o corpo é mídia, a um só tempo emissor e receptor. É, tanto quanto Exu, flu- 
xo. Como as águas de um rio heraclitiano, Exu Bará (a força do corpo de todos os seres vivos) atravessa e é atravessado por todos os movimentos do mundo. É, com isso, um corpo sensível e dinâmico, um corpo vivo, imanente e transcendente. Um corpo atravessado. E se o corpo se vê atravessado por esses movimentos, isso se manifesta em gestos.

\subsection{Exu Bará: um poeta no gesto}

Chamamos de gesto o movimento que atravessa o corpo e o impele a se mover de forma ao mesmo tempo consciente (sei o que estou fazendo e isso tem um significado), e inconsciente (não sei o que me move a esse gesto e não busco o significado, apenas sinto e vivo). Ou seja, há no corpo uma força incontrolada ao mesmo tempo em que há forças que permitem controlar os próprios movimentos. Essa força dinâmica que perpassa cada ser vivo e o impele ao gesto é Exu Bará. E, como vimos, é uma força que vai em direção ao futuro, mas que é mediadora entre passado e presente, entre ancestralidade e descendência, entre sagrado e profano, entre divino e humano.

Para entender a relação entre gesto e espírito, ou sopro animador das coisas, é preciso explicar que, no complexo sistema nagô, para cada elemento espiritual corresponde uma representação material ou corpórea e cada componente da personalidade é derivado de uma entidade original. Assim sendo, a cabeça de cada indivíduo - chamada Orí - é a realização material da força espiritual de cada ser, adquirindo assim um caráter sagrado. Por isso, tocar a cabeça de um iniciado será um sacrilégio; o que explica também o uso de panos enrolados na cabeça, na cor do orixá correspondente à característica de cada personalidade para as mulheres e o uso de tocas para os homens. Continuando nessa perspectiva, o Emí (sopro vital indistintamente do corpo e do espírito) é o princípio da existência insuflado por Exu Bará; ele reside no peito, nos pulmões e se manifesta pela respiração. Seu elemento original é Olodumare, a entidade suprema universal, a protomatéria do universo, o ar. Por isso, cada indivíduo é sagrado, em seu corpo e em seu espírito, e a respiração, além de ser fisicamente vital, o é também espiritualmente. Os pés, por estarem em contato com a terra, são as partes do corpo pelas quais os ancestrais montam, ou seja, é pelos pés que o indivíduo está conectado a seu passado ancestral. Ademais, cada pessoa possui dois tipos de memória: a que acompanha o Emí que é transmitida com ele e carrega a memória ancestral coletiva - diz-se inclusive que essa memória conduz Emí através da terra dos sonhos no sono e depois da morte; a outra é a que permite que as experiências sejam lembradas, estudadas e acumuladas - diz-se que essa memória acompanha a pessoa quando acorda e que é como uma bolsa que vai se enchendo à medida das experiências do indivíduo. Ou seja, existe uma memória coletiva e outra individual.

A concepção exposta até aqui, de um princípio dinâmico que anima todo ser vivo, chamado Exu Bará, faz parte de um complexo de realidade vivida e ritualizada nos terreiros afro-brasileiros nagôs, mas pode ser estendida ao humano em qualquer cultura sem que haja necessidade de recorrer à crença ou a um sistema religioso no sentido estrito; no entanto, se tomarmos a palavra religião no sentido lato contido na origem latina da palavra religare, entenderemos que o sistema nagô (como provavelmente todo sistema religioso em sua forma original) remete a uma ontologia universal. Com efeito, com a noção de Exu Bará, há uma religação entre as partes do sistema cósmico, no qual o indivíduo não está desconectado de seu meio social (a comunidade), nem do seu meio natural (os deuses correspondentes às manifestações da natureza), tampouco do que permanece misterioso (o Deus, Olodumare, do qual nada se sabe, que não possui linguagem, que simplesmente é). Nesse sentido, a concepção nagô exposta aqui possui um valor epistemológico capaz de alimentar nossa reflexão sobre o pensamento-corpo.

Essa concepção religiosa nos interessa também naquilo que ela tem de poético, uma vez que, conforme já enunciado por Novalis (1988) "a poesia é a religação originária da humanidade" e, conforme o poeta Juarroz (2000) "a poesia recupera o ser das coisas". Observar, compreender e até vivenciar os ritos afro-brasileiros do sistema nagô nos permite repensar essa possibilidade de religação através do poético.

Vejamos por exemplo que, para harmonizar-se consigo e com a natureza, no sentido corpo-espírito, o 
Iniciado aos mistérios dos Orixás não pode dever nada a $E x u$. Se não fizer suas oferendas, se não agradecer e pedir licença a cada iniciativa de conexão com as outras forças do mundo, seus caminhos serão fechados, o fluxo não circulará até que o sopro se faça cada vez mais raro e falte. Fica claro aqui que, longe de se tratar de uma crença primitiva impregnada de superstição e submissões arcaicas a forças amedrontadoras - o que redundaria em um sistema de controle - trata-se de um sistema poético-mítico no qual o dono das encruzilhadas, dos pontos de convergência e divergência, dos caminhos e portas não é outra coisa senão uma metáfora da força que permite que o sopro vital circule e anime a matéria, em íntima conexão com a alteridade. É o que Kamper chamou de "pensamento-corpo" e que vimos atualizado, como corpo vivo, na ideia de ar e sopro desenvolvida por Didi-Huberman em intenso diálogo com a psicanálise de Pierre Fédida e a poesia:

Lair est le véhicule, plus, le portant de la parole. Il est le milieu physique grâce auquel - et à travers lequel - elle nous parvient. Mais l'air est déjà, dans la bouche et les poumons du locuteur, la matière quasi organique par laquelle sarticule, saccentue, se respire et se module le phrasé de notre parole, de nos pensées. (...) une pensée de lair en tant qu'il serait, non seulement le véhicule de la parole - c'est-à-dire aussi de la plainte et $d u$ chant-, mais encore le milieu par excellence du figurable, le mouvement même, atmosphérique et fluide, de l'inconscient comme tel.3 (DIDI -HUBERMAN, 2005, p. 14-15)

O ar está portanto no corpo e na palavra. Manifesta-se como um sopro que conduz a fala e o gesto. É animado por um dinamismo que o movimenta e o faz circular. Quando representado por Exu, é o akotô, o caracol espiralar, símbolo autoexpansivo de crescimento. Buscamos, todavia, a fim de nos aproximar de um pensamento-corpo, uma forma de significar esse princípio do sopro dinâmico através de uma imagem que possa conter as quatro dimensões que nossa ciência antropológica já determinou em estudos voltados para as relações entre corpo, sentidos e linguagem. Para isso, na seção a seguir, propomos uma representação do corpo em cinco dimensões interligadas: a rosa.

\section{O corpo: uma rosa no centro do losango, geo- metria artístico-filosófica}

Apoiando-se nas reflexões de Vilém Flusser sobre o efeito histórico da abstração do corpo, Dietmar Kamper (op.cit.) o situa em um quadrado antropológico que mostra claramente a passagem da civilização por quatro dimensões que vão do corpo tridimensional, cujo horizonte é o espaço (corpo que ouve e fala), ao corpo bidimensional, cujo horizonte está na superfície (corpo que vê), a um corpo unidimensional, que tem por horizonte a linha (corpo que escreve e lê) e, por fim, a um corpo nulodimensional, cujo horizonte reside no ponto (corpo que calcula), grau máximo de abstração que finda por negar os sentidos do corpo. A essa realidade quádrupla que resulta num corpo de sentidos mortos, cuja racionalidade baseia-se em uma lógica cartesiana de relação ao mundo, Kamper acrescenta outra, a quinta dimensão: um corpo vivo, de uma realidade não-dimensional (que podemos portanto relacionar com a noção de Aberto, em Rilke, onde o horizonte é ilimitado) na qual o corpo sente e rastreia. Para falar dessas cinco possibilidades, Kamper remete ao pensamento hermético e ao pentagrama4:

A rosa na cruz da realidade é o velho nome
do zero, do nada, do espaço vazio, do buraco
no tempo, enfim, daquela ausência radical que
adquire contornos numa estética do ausente. O
pensamento hermético diz respeito à transição
do espaço ao tempo, do calcular e do ver à au-
dição e ao rastrear, do 'quadrado antropológi-
co' ao 'pensamento pático' dos sentidos e das
paixões, da filosofia do fundamento ao pensa-
mento-corpo. (...) Hermetismo, pode-se dizer,
é o saber da humanidade divina e da divindade
humana. Não se trata da identidade, tampouco
da diferença definitiva entre o divino e o hu-
mano, mas sim da constante troca entre ambos,
seu metabolismo. (KAMPER, prelo, p.114-115)

Vemos, portanto, que a estética do ausente, as faltas da linguagem de que nos fala Didi-Huberman, os brancos que devem ser acentuados, se ela se situa numa perspectiva anti-narcísica, não constitui com isso um nada desprovido de sentido e aniquilador; a ausência é plena de potência, potência de sentidos sensoriais, cujo caráter in- 
compreensível pode ser admitido na realidade corporal e, então, tornar-se significante. Admitir o incompreensível no sentido do corpo que rastreia e sente é admitir o sopro vital animador do "deus cujo nome está ligado a avanço/ recuo/travessia" (Exu para os nagôs afro-brasileiros):

Não há dados objetivos sobre a felicidade dionisíaca que é estar fora de si estando ainda em si, de somente na profundeza do próprio corpo poder estar com os deuses. O enigma da troca entre divino e humano, que é um metabolismo, ou seja uma troca material e não formal, consiste na impossibilidade de determinar tanto identidade quanto diferença, portanto na possibilidade de uma paradoxia excêntrica, de uma auto-contradição já sem nenhuma determinação central. Para ali chegar, é aconselhável a ajuda do deus cujo nome está ligado a avanço/recuo/travessia. Em estado sóbrio, não é possível entender o que se passa, passou e passará. (Idem, p. 129)

Para dar a entender a estética da ausência e a presença de um corpo num horizonte em cinco dimensões, com vistas ao aprofundamento das reflexões futuras sobre o corpo e seu lugar antropológico, trazemos considerações geométricas, fruto de um gosto pelas formas que a realidade transcendente toma em suas manifestações imanentes, uma vez que nos atemos, neste artigo, aos gestos do corpo (imanente) impelidos pela força de um sopro vital (transcendente). E inferimos que o corpo vivo de que Kamper nos fala pode ser representado e compreendido como uma rosa cujas pétalas vão se formando em uma sequência espiralar ascendente (enquanto se desenvolve para a vida) e descendente (enquanto evolui para a morte), assim como nos foi mostrado na representação de Exu como o akotô.
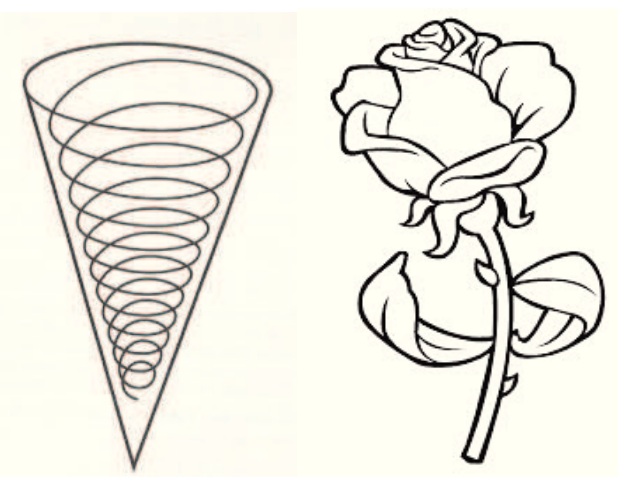

A rosa é aqui mais que uma imagem ou uma metáfora. Também não deve ser entendida - obviamente - em uma perspectiva esotérica. Não se trata disso. Trata-se da rosa enquanto ela é uma rosa; trata-se do real tal como podemos e não podemos apreendê-lo, sendo esse aspecto inapreensível fundamental para nossa concepção de pensamento-corpo. Trata-se da rosa como resultado de um sopro vital e dinâmico que conduz da potencialidade do real à sua realização, da semente à planta, da planta ao broto, do broto à flor cujas pétalas se organizam em espiral e formam o desenho harmônico de uma rosa que vemos e cujo cheiro sentimos.

A rosa é umas das representações do feminino e o sentido que estamos querendo significar com a ideia de corpo vivo e de sua dimensão inapreensível é o sentido feminino do corpo, não enquanto manifestação de sexualidade, mas enquanto um tipo de fluxo que obedece a uma lógica feminina, a da "ânima" que, de acordo com a concepção Junguiana é a parte imaterial do corpo, que surge das profundezas misteriosas, a parte que a razão não alcança, que vive por si mesma e que nos faz viver. "Não a alma no sentido dogmático, nem uma anima rationalis, que é um conceito filosófico, mas um arquétipo natural que soma satisfatoriamente todas as afirmações do inconsciente, da mente primitiva, da história da linguagem, da religião" (JUNG, 2011, p. 36). Na simbologia ocidental, a rosa, como o lótus egípcio ou o narciso grego, emerge das águas. Trata-se de uma força de regeneração e transformação mística. Talvez devamos dizer que a quinta dimensão buscada por Kamper na ideia de pentagrama ou de rosa no meio da cruz não é estranha ao fato de que, na mística do primitivismo cristão, o número cinco está, ele também, relacionado à ideia de renascimento e de início de um novo ciclo. De certa forma, o que queremos significar com a rosa é essa força viva do corpo, que o anima e o faz emergir em movimento e que o constrói e desconstrói num sentido espiralar, assim como a manifestação de Exu se dá como uma espiral atravessando o corpo vivo, animando-o.

Propomos, para abrir a reflexão antropológica sobre as relações desse corpo com a civilização e seu processo construtivo multidimensional, que essa rosa seja aqui também o quinto elemento que emerge ao centro 
de um quadrilátero (as quatro dimensões da imanência) que se configura como um losango por duas razões. A primeira é que o losango traz a ambivalência da harmonia masculino/feminino, o triângulo inferior para baixo sendo feminino e o triângulo superior para cima, masculino. A segunda é que o losango repousa sobre uma ponta, como o akotô, representando o pé-raiz, o princípio universal que dá origem a todas as coisas. Assim sendo, propomos a seguinte representação de nossas reflexões sobre o corpo:

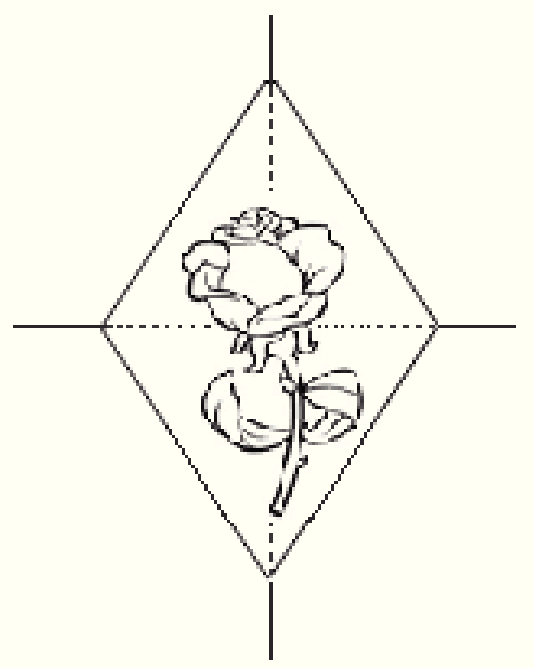

Um desenvolvimento possível já pode ser pensado a partir dessa representação, se acrescentarmos sentidos às quatro direções implícitas no losango. No eixo vertical, estariam, na direção superior o corpo civilizado (morto em vida) tencionando-se na direção inferior com o corpo selvagem (vivendo a morte). Esse eixo vertical apresenta, portanto, dois polos tensionados, porém não contraditórios, como duas dimensões da nossa relação ao corpo: a do corpo natureza, instintivo, sensível a tudo, que necessita de uma ordem para viver sua própria intensidade e a do corpo civilizado que, como vimos anteriormente, necessita ser atravessado pelo sopro animador sob pena de aniquilamento e morte em vida. No eixo horizontal, do lado direito, o corpo teatral (expressão) tencionando-se na direção da esquerda, com o corpo médium (impressão). Aqui também o corpo da expressão não escapa à lógica da re- presentação que se percebe como fora do real enquanto o corpo da impressão é em tudo sensível ao que se passa no mundo e dele inevitavelmente participa. Dessas relações de tensão e equilíbrio, entre o selvagem e o civilizado por um lado e entre a expressão e a impressão por outro, emerge a rosa (o corpo vivo).

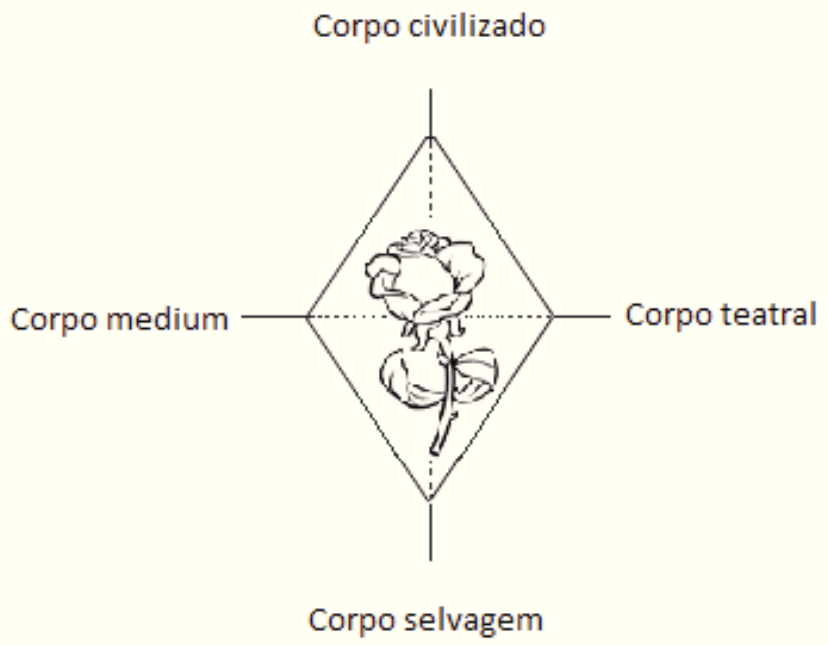

Chamamos essa representação final, que é, na realidade, um novo ponto de partida para nossas reflexões em movimento, de "geometria artístico-filosófica" por acreditarmos que ambas, arte e filosofia, se unem na busca de um discurso não apenas movido por argumentos exclusivamente racionais e lógicos, mas também por argumentos sensoriais: sopro do ar e do movimento animando um pensamento-corpo em cinco dimensões, a quinta sendo a dimensão poético-mítico -espiritual do incompreensível: a dimensão pertencente a Exu, esse "deus cujo nome está ligado a avanço/recuo/ travessia", dono das encruzilhadas, força dinâmica capaz de fazer emergir ao centro do losango das manifestações corporais um corpo vivo, habitado por Exu Bará. 


\section{Notes}

1. Exu é uma divindade cosmogônica central no sistema nagô. Sendo o princípio da manifestação das forças universais, ele é tudo e está em tudo. $\mathrm{O}$ atributo de Bará para Exu pode ser desdobrado em obá (rei) + ará (corpo), resultando em Exu Bará como Exu o Rei do corpo. Isso significa que um dos desdobramentos de Exu enquanto divindade é aquele de Rei do corpo, ou seja a parcela dessa divindade que vive em cada um e anima o corpo de cada ser vivo.

2. Acentuar as palavras para fazer dançar as faltas e lhes dar potência, consistência de meio em movimento. Acentuar as faltas para fazer dançar as palavras e lhes dar potência, consistência de corpos em movimento (tradução nossa).

3. O ar é o veículo, mais, o portador da palavra. É o meio físico graças - e através do qual - ela nos alcança. Mas o ar é, já, na boca e nos pulmões do locutor, a matéria quase orgânica pela qual se articula, se acentua, se respira e se modula o fraseado de nossa fala, de nosso pensamento. (...) um pensamento do ar enquanto este seria, não só o veículo da fala - ou seja, também da lamúria e do canto -, mas também o meio por excelência do figurável, o movimento mesmo, atmosférico e fluido, do inconsciente enquanto tal (tradução nossa).

4. É interessante notar aqui que, no sistema afrobrasileiro, Exu é equivalente ao deus Hermes da mitologia grega e que o pentagrama também pertence à simbologia da Umbanda, tendo vários significados expressos pelas cinco pontas, como os cinco sentidos, os cinco elementos e a vitória do espírito sobre os quatro elementos da matéria: terra, água, fogo e ar.

\section{Referências}

BENJAMIN, Walter. Teses sobre o conceito de História. In Walter Benjamin - Obras escolhidas. Vol. 1. Magia e técnica, arte e política. Ensaios sobre literatura e história da cultura. São Paulo: Brasiliense, 1987.

CASTRO, Gustavo e DRAVET, Florence. Comunicação e poesia - itinerários do aberto e da transparência. Brasília: UnB/Finatec, 2014.

DIDI-HUBERMAN, Georges. Gestes d'air et de pierre corps, parole, souffle, image. Paris: Minuit. 2005.

FÉDIDA, Pierre. "Passé anachronique et présent reminiscente. Épos et puissance mémoriale du langage", Lécrit du temps, no 10, 1985, p. 23-45.

. «Le souffle indistinct de l'image» (1993), Le Site de l'étranger. La situation psychanalytique, Paris, P.U.F., 1995, p. 187-220.
JUARROZ, Roberto. Poesia e realidade. Brasília: Casa das Musas, 2005.

JUNG, Carl Gustav. Os arquétipos e o inconsciente coletivo. Rio de Janeiro: Vozes, 2011.

KAMPER, Dietmar. Mudança de horizonte - um sol novo a cada dia, nada de novo sob o sol, mas... Tradução Danielle Naves. São Paulo: Paulus (prelo).

MATHET, Marie-Thérèse. (sous la dir.) L'incompréhensible - Littérature, réel, visuel. Paris: L'Harmattan, 2003.

NOVALIS, Pólen. Fragmentos, diálogos, monólogo, introdução, tradução e comentários de R.R.Torres Filho. São Paulo: Iluminuras, 1988.

SANTOS, Juana Elbein e SANTOS, Descoredes Maximiliano (Mestre Didi Asipa). Eșú. Salvador: Corrupio, 2014.

Recebido em: 15/04/2015 Aceito em: 14/09/2015 
